\title{
Comparative Politics of Natural Resource-Dependent Countries: Mongolia in a Comparative Perspective
}

\author{
Turtogtokh Janar \\ National University of Mongolia, Ulaanbaatar, Mongolia \\ Myagmarsuren Dashzevge \\ Mongolian University of Science and Technology, Ulaanbaatar, Mongolia
}

\begin{abstract}
Mongolia has been facing a lot of challenges to build a democratic society and to develop democratic governance, solving political, economic and social problems, and overcoming those obstacles and difficulties, which have derived in our new times. Mongolia is a new democracy, which is implementing political and economic transition reforms simultaneously. Some initiatives on and challenges for development of the country which based on mining of natural resources of Mongolia have appeared in recent years. This paper discusses about the outcomes of natural resources, especially, political and economic impact of resource cure in cases of Mongolia, Kazakhstan, Kyrgyzstan and Myanmar in a comparative perspective. The research considers the following institutional factors of resource impact which include governance and management systems, corruption level, and geopolitical conditions and resource nationalism. The analysis was conducted based on comparative study of international research institutions such as resource governance index, researches on corruption, and political and geopolitical risks, surveys that estimated political situation and policy consequences relating to natural resources in abovementioned countries and self-collected data and facts.
\end{abstract}

Keywords: resource-dependent countries, neopatrimonialism, resource nationalism, resource geostrategic curse

\section{Introduction*}

Mongolia is a rich country with a lot of natural resources. In the country there are several mining deposits of gold, copper, uranium and raw petrol which are considered to be necessary for world economy. However, it goes also economy is likely to depend on how to use and manage natural resources, and is depending on its natural resources, especially world rate fluctuation of gold and copper. In a reality, the experience shows that the economy which is rich in natural resources are slowly growing than the economy with insufficient natural resources, as well as negatively influencing on the political system. The natural resource itself has brought many difficulties to the governments of the developing countries, causing instability and negative consequences of political and economic life.

Turtogtokh Janar, Ph.D., Professor, Department of Political Science, National University of Mongolia.

Dashzevge Myagmarsuren, Ph.D., Senior Lecturer, Department of Social Sciences, Mongolian University of Science and Technology.

* This research survey has been done within the framework of the research project on "A Comparative Study on Political Economy of Natural Resource Based Developing Countries: In Case of Mongolia, Kazakhstan, Kyrgyz, Myanmar and Vietnam” supported by the National University of Mongolia, Ulaanbaatar, Mongolia, 2015. 
In Kazakhstan, Kyrgyzstan and Myanmar, until recently the authoritarian or communist political structures and centrally planned economic system have dominated and over the last couple of decades they have been under the political and economic transition and implementing reforms. Moreover, these countries are rich in mineral resources and mineral extraction which plays an important role in forming the national budget and same time ongoing processes on political institution reforms, which brings them to the edge of duplications and conflicts of foreign players/investors interests, overcoming risks of the country's geopolitical situation and security caused by external rent.

As noted in recent studies on natural resource political economy, extractive revenues should help resource-rich countries to mobilize domestic resources for social and economic development, in particular during price booms. Yet in practice, economies abundant in natural resources have tended to grow slower than economies without substantial natural resources (Carbonnier, Wagner, \& Brugger, 2011).

Political economy scholars such as T. Karl, M. Humphreys, P. Collier, J. Sachs, J. Stiglitz, M. Ross, R. Auty and others have been studying impacts of natural resources on economic performance and political institutions. As of those studies, the resource-rich countries tend to grow slower in comparison with the resource-poor countries and face political and economic challenges and difficulties caused by mining. For instance, political instability and a change in ruling regime are likely to emerge in resource-dependent countries with budget instability and economic crisis. Alongside these growth failures are strong associations between resource wealth and the likelihood of weak democratic development, corruption, and civil war.

Thus, the problems occurring in resource-dependent countries have been determined in the concept of "resource curse". Especially, the perverse effects of natural resources on economic and political outcomes in developing states give rise to a wide array of difficult policy questions for governments (Humphreys, Sachs, \& Stiglitz, 2007). For instance, there have been social instability and internal conflict escalated repeatedly due to unequal distribution of mining revenues. Moreover, the resource curse is thought to have significant detrimental consequences in terms of the development of political pluralism and personal freedom (Stoddard, 2012). Several examples of having instability and national security issues in resource-rich countries because of overlap and conflict of external players' interests and external rent have been researched within the concept "geostrategic curse" (Shahyrov, 2014).

\section{Political, Economic Transition and Resource-Curse}

The countries surveyed are located in sub-regions of Asia such as Northeast Asia, Central Asia and Southeast Asia. They differ from each other in geography, history, population, and ethnic, religious, cultural, political and economic systems. However, until recently a centrally planned economic system and a Soviet-style political regime were dominating in these countries and over the last two decades those countries have been implementing reform designed to overcome the difficulties of political and economic transition processes. Among the facts that these countries are rich in mineral resources and the mining plays an important role in the economy, there are few more common facts that the consequences of the mining impact on the political system have been observed and they are lower-middle-income or low-income countries.

There have been certain measures taken in the countries surveyed on reducing the political control and participation in the social life in terms of the politics, ensuring the implementation of human rights, and steps taken towards democratic transition despite the difference in the scale. Moreover, the liberalization of centrally planned economic system and the process of transition to a market economy have been in progress. 
As a result of the ending of the Cold War, the Soviet Union collapsed; Kazakhstan and Kyrgyzstan which were parts of it gained their independence, the communist regime and a centrally planned economic system were replaced and the transition of regime began. In these two countries with Post-Communist regimes, the autocratic regime was dominating where the power is in hands of one person. During the time, Kazakhstan successfully managed to conduct the economic reform. However, the international studies show negative highlights on corruption, citizens' political and economic freedom index of this country.

In 1990, the "democratic change" was one of the key goals of the President of newly independent Kyrgyzstan A. Akayev and until the beginning of a new century the country observers were magnifying it as an "Island of Democracy" (Anderson, 1999) in Central Asia. However, the poor economy, corrupt political system and clan political conditions led to the revolution in the country twice, researchers conclude. Consequently, in 2010, as a result of so-called "color revolution" or the universal uprising, the new constitution was approved and the autocratic regime was abandoned and replaced by the parliamentary regime.

Formerly a member of the socialist camp, Mongolia launched democratic reform in 1990 and adopted a new constitution in 1992, thus, the governance consisted of democratic political system and free economy has been validated and secured in the country. Mongolia has been considered as a state that successfully joined the line of the democratic countries where the freedom of the press, civil political rights and economic liberalization process has been considered as successful. However, the country is considered as one of the states with raised poverty and black economy because of the economic shock therapy, corruption and weak government institutions.

Gaining the independence in 1948, Myanmar (formerly Burma) laid a foundation of social change only in 2008 by a constitutional universal referendum as a result of many years of struggle against the socialist orientation military dictatorship which had existed since the 1960's. Furthermore, even though the civil governance based political and economic reform process has been accelerating, the country is facing multiple challenges as a result of long-lasting civil war, conflict of armed groups, corruption, weak institutions and isolation from the outside world.

Although, the resource-reliant economies of the abovementioned countries played an important role in order to overcome the difficulties related to political and economic transition, it has caused difficulties in ensuring the development of newly established governance institutions and consistent adherence to policy, and has implicated adverse impact on the implementation of political and economic transition in such ways as making the countries be influenced by non-state actors and creating potential risk to the security and so on.

First of all, there is a question raised whether the countries surveyed are resource-reliant and are resource cursed or blessed ones. In 2012, the International Monetary Fund released a document named "Macro-economic policy framework for resource-rich developing countries, according to which Mongolia is among resource-rich developing countries, Kyrgyzstan is among prospective natural resource-exporting low-income countries, and Kazakhstan is among upper-middle-income resource-rich economies (IMF, 2012). As for Myanmar, it did not present any national data so it was included in the comparison group; however, it was not studied and classified.

In his books on The Bottom Billion (2007) and Wars, Guns, and Votes: Democracy in Dangerous Places (2009), P. Collier listed 58 countries which fail to progress because of conflicts, natural resources, landlocked location and poor governance, and are in need of international aid and support inlcuding Mongolia, Kyrgyzstan, Kazakhstan and Myanmar. Haber and Menaldo (2011) classified Mongolia and Kyrgyzstan as Potentially 
Resource-blessed Countries democratic countries, while classified Kazakhstan as a Neither Blessed nor Cursed autocratic state. The research is focused on the impact of natural resources on the polity of the resource-rich countries. In other words, the conclusion was made based on measuring democracy by measurement units such as competitiveness of political participation, and openness and competitiveness of executive recruitment.

However, the Oxford Policy Management Center survey conducted in 2011 shows that a country is defined as mineral dependent if minerals account for $25 \%$ or more of its tangible exports. Among the mineral-dependent countries accoring to the survey, there are Kazakhstan, Mongolia, Kyrgyzstan and Myanmar and the comparative analysis between 1995-2010 reveals that the mineral dependancy of these counties increased. Moreover, the survey has determined the resource curse vulnerability of several countries. As the economic and institutional development indicators were surveyed, the study classifies Mongolia as a country which is especially vulnerable to the "resource curse"- the risk that substantial changes in commodity prices will severely affect its development with limited industrial diversification and institutional development ranking. However, Kazakhstan was estimated as a heavily mineral-dependent, its ranking of performance of economic development and institutions was reasonably high (Haglund, 2011).

From there the political criteria and economic development meausrement have been considered separately for the assessment of the "resource curse". In other words, while due to the democratic political criteria Mongolia and Kyrgyzstan are considered as non resource cursed, in terms of the economic institutional criteria, these are vulnerable to the resource curse. As for Kazakhstam, it is classified as non resource cursed by the the economic measurement, but by the democratic criteria it is in between.

According to Mehlum, Moene and Torvik (2006), natural resources encourage "production friendly" institutions, with "grabber friendly" institutions there are gains from a weak rule of law, malfunctioning bureaucracy, and corruption. In other words, the resource curse is the main source of institutional degradation. In the World Bank's “Worldwide Governance Indicators" survey, government effectiveness, regulatory quality, and control of corruption in Kazakhtsan, Kyrgyzstan, Mongolia and Myanmar are at the different levels (WBG, 2014). However, Mongolia and Kyrgyzstan have reasonable institutional indicators in the comparison by country, it decreased between 2000-2013. Meanwhile, the governance institutional indicators of Kazakhstan relatively increased. In summary, the "mining boom" that has taken place in Mongolia and Kyrgyzstan since 2000 has negatively influenced on their governance institutions.

In the conference on "Institution Building and Economic Development in Central Asia" which held in Alma Ata, Kazakhstan in 2008, the followings were determined as main reasons of resource curse. These include: (1) Macro-economic management problems. The key factor is the Dutch disease which causes imbalance between economic sectors when the nation's currency becomes stronger because of large-scale exports of mineral commodities; (2) Revenue instability caused by fluctuations in natural resource prices disrupts the sustainable management of the national financial debt; and (3) Adverse impact of large state budget revenues from natural resources on national institutions and governance.

Summarizing the pre-cited international organizations and researchers' studies, it is observed that Mongolia, Kazakhstan, Kyrgyzstan and Myanmar constitute resource-dependent developing countries in the process of political and economic transition and there are similar circumstances arose from socio-political traditional institutions, economic system and mining. All the consequential phenomena of a resource-reliant economy that are "resource nationalism", corruption and patronage government have been noticed in those countries, and these phenomena are to hold up the countries' political transition and socio-economic 
development quite intense.

It is common to define political institutions of the resource-rich countries in the concept of rentier states. This concept was developed by Mahdavy in the 1960's by analyzing the economic problems in Iran. Rentier states are defined here as those countries that receive substantial amounts of external rent on a regular basis and because of a dominant role of the government in the resource revenues distribution, the government domination in the country's economy starts expanding (Mahdavy, 1970). Those substantial amounts of external rent encourage the increase of corruption and the clientelism of political institutions which often leads to a patronage government type. In other words, centralization of the state power in hands of an individual or a group of individuals systematically and gaining and distribution of the resource revenues and external rent by an empowered minority has been enabled.

According to Dr. Becks' classification, the rentier states are divided into high level (40\%-50\% of the budget revenue), middle level (30\%-40\%) and lower level (20\%-30\%) countries by the size of external rent in the budget revenue (Martin, 2007). Regarding Kazakhstan, 60\% of the state budget consist of oil revenues, however in Mongolia $40 \%$ of the state budget is completed from the mining sector. About $10 \%-15 \%$ of the Kyrgyz state budget consists of gold mine revenues, while 30\%-35\% of Myanmar's national revenue comes from natural gas exports. During the military regime powered until 2011, more than half of the state budget consisted of natural gas and oil revenues. Apparently, the rentierism of the countries surveyed is at different levels.

Generally, it is observed in the studies that in the countries with the tradition of clan politics, the "neopatrimonialism" is widely spreading. The allocation of the rent to the family, the home region or the ethnic community, geographic regions, and economic clans differs based on the political and economic structure of the country (Schweickert, 2015). Leaning on their analysis on the political governance of the Central Asian countries, Gawrich, Melnykovska, and Schweickert (2010) categorized the neopatrimonialism in those countries as follows: (1) Sultanistic neopatrimonialism has a very strong concentration of power in an impermeable narrow circle of power elites; (2) Oligarchic neopatrimonialism maybe characterized by patronage or rent-seeking cycles, which are linked with government institutions with strong competition between them; (3) Bureaucratic neopatrimonialism or bureaucracy representatives show a monopolization of power which is based on informality; and (4) Soft neopatrimonialism is defined as governance systems which are already based on less informal mechanisms.

Kazakhstan is one of the highly dependent on natural resources such as oil, natural gas countries or is a resource-reliant economy. As a former Soviet state, since 1991, it has launched political and economic reform, especially, adhering to a policy on privatization and liberalization of the state owned enterprises in order to raise foreign investment for the mining sector. On the other hand, since 1990 up to now, there has been a narrow rent-seeking clan system established, which makes decisions through today's President N. Nazarbayev, his family and close friends. This clientelist system of a narrow circle which surrounds the patronage president is categorized as Sultanistic neopatrimonialism. Although the system ensures the political regime stability and economic growth in the country, it becomes a reason of increase of corruption level, and to fold the political competition and a rule of law.

Kyrgyzstan has had an unusual clientelist clan system which "feeds" its political groups with foreign aid and resource revenues since the periods of 1991-2005 when A. Akayev was the President and 2005-2010 when the President was K. Bakiyev. In fact, the Tulip Revolution that took place in 2005 in the country was just a 
replacement of one resource controlling and corrupt clan by another. The system where the power has been used for the strengthening of surrounding persons and clan is categorized as Oligarchic neopatrimonialism by the researchers. However, the parliamentary system of governance was adopted in 2011 and the state is aiming to establish a democratic system, the political actors still have been driven by neo-patrimonial links and indicators on corruption control, implementation of law and public liability. The traditional networks based on home regions and family contacts now have been transformed into the networks of political party factions, non-parliament political forces and business groups (Marat, 2012). In other words, the resource abundance in those countries has sustained a clan political and economic system based on the culture of corruption and rentierism, originated from the Soviet system.

Since 1992, Mongolia has adopted parliamentary system, so far, political and economic transition has been keen to implement rapidly. Newly established political parties and political forces have been competing for control of the state-owned mining industries in order to gain necessary means of subsistence. Appointing the management leader of the Mongolian-Russian joint venture "Erdenet", which constituted $60 \%$ of the state budget until recently, as a matter of priority has become a habit of a party just after came into power. Furthermore, the "mining boom" which took its origin from the mid 2000 laid the foundation for fierce competition between political and business groups who have interests to control larger mining deposits and to have access to income derived from the rents. In particular, political parties and forces elected to the parliament have been actively protecting and promoting the interests of the mining companies through the law making power and government decision-making mechanism. The restriction process of impact force of the competing business groups through the power of the law enforcement institutions such as judiciary and anti-corruption body is underway in the country. Entirely, the democratic system in Mongolia has been formed as clientelism, and the Oligarchic neopatrimonialism has been brightly presented.

Until 2011, Myanmar had been a socialist country and the authoritarian military dictatorship with one-party system. The political institutions of Myanmar which are in the transition to a civil and democratic regime have made significant steps towards proper handling of resource management and keeping away from the resource curse. However, the influence of the military forces with long time period domination has remained, especially; it has been used as a driving force for the rent-seeking military companies and ethnic armed groups to encourage corruption in the natural resource sector and non-transparency of the governance (Treffers, 2010 ). However, it is too early to anticipate that the newly formed democratic regime institutions are likely to have patronage and clientelist characters in the future, the quality of the county's institutions will depend on how optimal the government policy and management are.

One of the reasons that the resource-rich countries have poor governance is the resource mining revenues lead the government accountability to failure, and those revenues have been grabbed and played about in trade of the corruption. As the "Corruption Perceptions Index" by the Transparency International shows (see Table 1), the countries surveyed are included in the corrupt countries category. However, each country has managed to level down the corruption, it is hard to say that corruption occurred and was increased because of resource abundance, and also hard to deny that the corruptness in those countries has been affected by the resource-dependence of the countries.

Myanmar is one of the resource-rich countries in South Asia and it was considered as country with the highest level of corruption among the countries surveyed. For instance, this country is rich with natural gas resources and one of the largest exporters of natural gas in the region. The natural gas revenues expenses were 
not clearly stated during the military dictatorship headed by Than Shwe (1992-2011). At that time the natural gas revenues constituted a half of all exports revenues and it was the largest source of the foreign income of the country. One economic analyst explained in 2009 that Burma currently receives between $\$ 1$ and $\$ 2$ billion a year from its sales of natural gas to Thailand, but these funds are kept far from the country's public accounts. They are squirreled away offshore and in local banks accessible only to the top leadership of the State Peace and Development Council. The military regime has hidden 99\% of the Yadana gas exports from 2000 to 2008 (an estimated US $\$ 4.80$ billion) and this unrecorded revenue could build more than 200,000 schools for 30 million children (AOW, 2012).

Table 1

Corruption Index by Country

\begin{tabular}{llll}
\hline & \multicolumn{2}{c}{ Score/Rank } \\
\cline { 2 - 4 } States & Year 2000 & Year 2008 & Year 2014 \\
Mongolia & 90 states & 180 states & 175 states \\
Kazakhstan & - & $3.0 / 102$ & $3.9 / 80$ \\
Kyrgyzstan & $3.0 / 65$ & $2.2 / 145$ & $2.9 / 126$ \\
Myanmar & - & $1.8 / 166$ & $2.7 / 136$ \\
\hline
\end{tabular}

Source: TI, 2014.

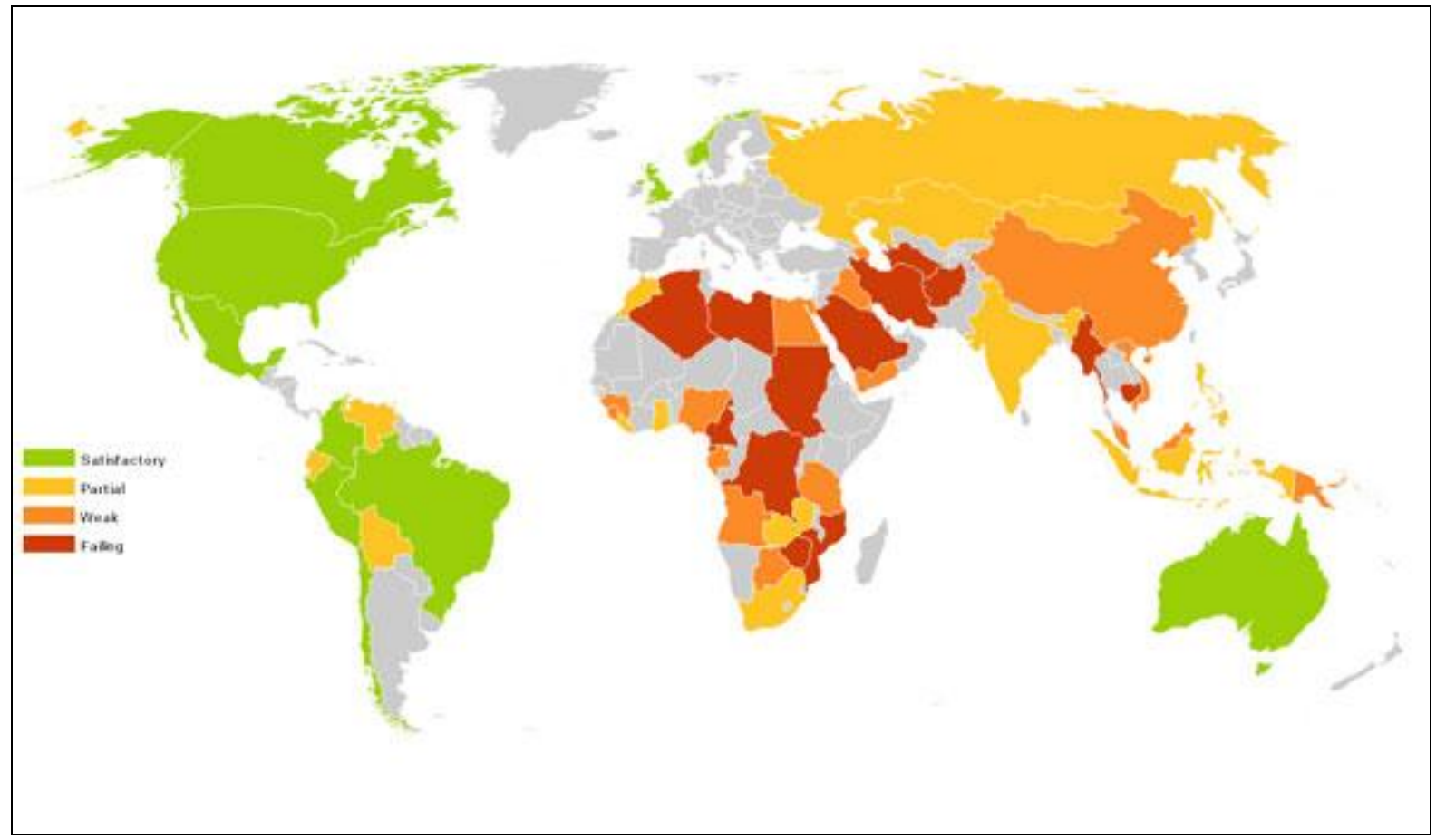

Figure 1. Resource Governance Index 2013.

Source: Retrieved from http://www.resourcegovernance.org/rgi/countries

It is available to determine the resources governance level of the resource-rich countries by identifying the development mining related institutions of those countries. For instance, according to the "Resource Governance Index-2013" survey conducted by the "Revenue Watch Institute", 58 countries' oil, gas and mining 
sector governance quality indicators have been rated and listed in accordance with four criteria such as institutional and legal Setting, reporting practices, safeguards and quality controls, and enabling environment. In this Resource Governance Index, Kazakhstan possessed the 19th place, Mongolia the 26th getting a "Partial" mark and Myanmar was listed in the last place or as the 58th and was included in the Failing classification (NRGI, 2013). Kyrgyzstan was not covered by the survey.

When looking at the abovementioned analysis and the international organizations' surveys results, the political and economic transition's consequences and resource reliant development conditions are possibly concluded as correlated in the countries surveyed in this comparative study. Due to Basedau's (2005) conclusions, in order to calculate the dynamics of resource politics, it is necessary to consider the country-specific conditions (level of development, political system, externalities, behavioral patterns of actors etc.) alongside with resource-specific conditions (type of resources, location of resources, resource revenue management and involved governments and companies). On the other hand, the abundance of resources and resource-dependence influence on socio-economic development and the quality of institutions and governance. In other words, it can be concluded that because of the interaction between political institutions transition and resource-reliant economy in the resource-rich developing countries, these countries become affected by the "recourse curse".

\section{Geopolitical Conditions and Resource Nationalism}

Alongside with many positive and negative impacts on domestic politics and institutions, resources cause external risks and problems. Resource-producing countries permanently attract industrialized and raw materials imports dependent powers and profit-orientated multinational companies. However, it makes possible for those countries to attract external players, export their resources and benefit; it also originates issues on security and policy stability of the countries, according to the studies of Basedau and Mehler (2003). Due to these studies, sometimes the competition between foreign states to take control over the resource-rich countries leads to war and rivalries. Mongolia, Kazakhstan, Kyrgyzstan and Myanmar have never been in conflict situation caused by foreign influence. However, their neighboring powers and the states with resource sharing interests have brought those countries to policy instability as they dread for being influenced by foreign players. Thus, those resource-rich countries are willing to apply a strategy to avoid being affected by resource nationalism either in society or political surroundings and possible danger.

All of the countries surveyed adjoin China which has been considered as a global player with positive policy on importing raw materials and resources necessary for the rapidly growing economic development. Consequently, China's neighboring countries who supply their raw materials to China have been beware of possible geopolitical risks to their national security and sovereignty because of their geopolitical game and a single market dependent supply. Despite the fact that Mongolia, Kazakhstan and Kyrgyzstan are landlocked, and Myanmar has an outlet to the sea, all have been pursuing a same geopolitical strategy to ensure involvement of not only the secondary but the third force in order to avoid dependency on their neighboring power. In particular, Mongolia, Kazakhstan and Kyrgyzstan have implemented a unique policy to ensure balance of power among the major players in the region.

As the mineral exports are an important factor of national security and country's development, the diversification of supply and building a wide network of infrastructure create big challenges for the policy makers. In terms of the countries surveyed, they have desired to diversify as much as possible their supply of 
mineral and raw materials which plays a major role in the investment and economy, thus avoiding dependency on a single importer power. Particularly, since the 1990's, Kazakhstan has conducted an active policy to promote direct investments by Western developed countries in the fields of energy and mining. In addition, during the recent years, it has intensively utilized the networks of oil and gas pipelines and old railways built during the Soviet Union, and implemented the establishment process of an infrastructure network with China. Mongolia, since the declaration of a third neighbor policy in the 1990's, has been adhering to a strategy to promote Western investment in the mineral resources sector. Moreover, Mongolia aims at building a network of railways connecting its major mineral deposits with both Russia and China, and avoiding dependency on any of its neighbors. Regarding Myanmar, China, Thailand and India are the neighboring countries of this country and they are mostly interested in energy and natural gas resources of Myanmar. The liberal regime, which has been in operation since 2011 is pursuing an active policy on the expansion of the energy supply infrastructure network towards its three neighboring countries, and the diversification of investments by them in Myanmar.

Serious problems have blown up in the abovementioned countries when those try to mix well with the transnational corporations and countries that have interests to make investments in the mineral resources sector and benefit, and meet their personal and national interests. For small economies such as Mongolia and Kyrgyzstan, there have been challenges occurred in balance ensuring during the process of negotiations with larger foreign companies interested in mineral resources exploration and production in those countries. Here is a case of the "Kumtor" gold mine, which is still on a debate, that the government of Kyrgyzstan has adopted more than one executive decision on reconsideration of the agreement with the Canadian "Centerra Gold" company signed in 1997, and transfer of the mine to the state property. Another example is there is inapprehension is still going between the Mongolian government and the foreign investors, even though the negotiation process on co-mining and exploitation of the major gold and copper mine of Mongolia "Oyutolgoi" started in the mid 1990's by the world's largest corporations such as "BHP", Ivanhoe Mines and Rio Tinto, and ended up with the signing of an agreement in 2012. In fact, the negotiations on the allocation of the resource rents between the foreign participants and the national government cause problems not only in Mongolia or Kyrgyzstan, but also in Kazakhstan which has long-term experience in cooperation with foreign investors.

Political and economic instability takes place when the government institutions' efforts to resolve a conflict of interest between the foreign players such as the neighboring countries and the transnational corporations, and the domestic players cannot reach any results. It is observed in the "resource nationalist" approach in those countries. To restrict and resist the involvement of foreign states and international companies in the mineral resource mining sector, and withhold the profit sharing is common in the resource-rich countries. Ernest Wilson has mentioned about this phenomenon in his theory the "Petro-Political Cycle" that it happens frequently under the influence of the price fluctuation of each kind of raw materials. Due to him, for example, an oil sector becomes politicized as much as the high prices on it, and the government that managed to save capital and technology decides to become as independent as possible from foreign companies.

A similar phenomenon occurred in the 2010's in Mongolia, when the Parliament of Mongolia adopted a law in a short period on restriction of the growth of foreign investments and increase of the government involvement in the mining exploration and production sector as the copper prices increased at the world market, however, because of the landslide of the price, it terminated all the law provisions immediately in order to overcome the economic obstacles. One thing that is related to the mineral resources exploitation is the direct foreign investment in the mining sector. The Mongolian government is being cautious about the oversized 
investments by any of the powers in the mining sector; it has also been focused on ensuring the investments in Mongolia to be beneficial for the Mongolian side. In the investments in the mineral resources sector of Mongolia, China accounts for a larger part. So, in order to restrict China's influence, the Parliament of Mongolia adopted the Foreign Investment Law before the 2012 Parliamentary elections which has caused a number of conflict issues.

Since the mining projects raising, a number of social and political movements such as "Civil Movement for Healthy Society", Radical Reform Movement", Civil movement for development" and movements for land nature, and environment protection such as "The River Ongi", "The Land of our Mongolia" and "Movement for Fair Privatizing of Land" have been actively operating, demonstrating and organizing assemblies with certain requirements to government, raising political issues. The "Oyutolgoi" mining project, which has been under the dispute since 2009, is another important subject for the resource nationalism.

Political parties and politicians that are elected in the parliament as well as civil society movements have been constantly expressing their positions on reconsider or terminate the three-sided contract signed between Mongolia and the "Turquoise Hill Resources" shared by the Canadian and British transnational corporations on the exploitation of the "Oyutolgoi" mining which is one of the world's largest gold and copper reserves deposits. The disputes on geopolitical issues such as defining the involvement of the states and transnational corporations that are interested in the investments in the coking coal reserves rich "Tavan Tolgoi" deposit, and establishing coal transport rail routes have not been resolved yet. However, the newly appointed government of Mongolia in 2012 has been promoting its actions towards creating friendly environment for the foreign investors, there have been attempts made by civil movements and local dwellers to resist and stop the exploration and production conducted by foreign companies.

To ensure the balance between its external politics and economy has become a serious challenge for the foreign policy of Kyrgyzstan because of its traditional political and economic relations with Russia developed under Russia's auspices, and regional situation which has been becoming more and more dependent on Chinese economic growth and influence in recent years. However, the country has abundant resources; it is in a lack of technology, capital and human resources necessary for the mining production. It is available to recover all these shortcomings by the cooperation with foreign partners, however there is a fear to become dependent on those partners and get the "unfair" profit share among the politicians and the public. One example for this is the willingness to develop autarchically.

Kyrgyzstan is the second largest gold producer in Central Asia. There have been ongoing disputes for many years on the "Kumtor" gold mine of Kyrgyzstan, which is one of the richest with reserves in the world. The Kyrgyz authorities have repeatedly attempted to reconsider the agreements and contract and to transfer the deposit to the state property since the mining started in 1997 with 100\% investment by the Canadian "Centerra Gold" company. In 2013, there were incidents committed by local citizens as they brought damages to the gold mine. By 2014, the "Kumtor" accounted for 7.4\% of Kyrgyz GDP and 15.5\% of its industrial output. Gold, which besides "Kumtor" includes several small mines, made up 41\% of all Kyrgyz exports in 2014 (Reuters, 2015). Another often resented practice by Chinese corporations is the wholesale import of their labor force. While many people in Kyrgyzstan may welcome Chinese capital, they do not see the need for these companies to bring most if not all of their employees from China, instead of recruiting locally. Furthermore, this deprives Chinese investors of local support, and instead of gaining them friends in their areas of operations it only prompts opposition (Calvo, 2014). 
A major part of Myanmar's foreign direct investment has been spent on the exploration and production of oil and gas. As of 2012, $88 \%$ of the foreign direct investment was allocated alone to energy, oil, gas and mining sectors. Investors are operating new discovery of off-shore gas and oil fields by production sharing contacts. More than one third or 36\% of imports are sourced from the China alone, $24 \%$ from Thailand, and 16\% from Hong Kong (EDB, 2014). In 2012, the parliament of Myanmar amended the Foreign Direct Investment Law by which the foreign investment in the environmentally unfriendly and unhealthy sectors, also in the sectors that are available for run by the local communities was restricted. Thus, it has caused problems to realize in real life.

Although the Kazakhstan's authorities have been seeking an open liberal policy on the foreign investments, it has experienced pursuing a policy on expansion of its control by demanding to increase the size of Kazakhstan's ownership and the profit share, and reconsider the Agreement on stability, with the increase of the oil and gas price at the world market.

The resource nationalism in the countries surveyed can be explained by the economic reason determined in the "Petro-political cycle" by E. Wilson, also the policy instability in a country affected by the neighboring powers' and transnational corporations' competition and influences, and caused by their interests to exploit the resources of that country can be considered in the concept "geostrategic curse".

Due Shahyrov (2014), the geostrategic curse is the adverse impact of external rent of natural resources in resource-rich countries and explicit and implicit policy pursued by neighboring countries on the development of political and economic institutions. Even though the resource-rich developing countries desire to conduct an independent strategy on mineral resources mining and production, it happens that those countries are affected by the "resource geostrategic curse" because of a few domestic problems such as weak government institutions, poor resource governance and management experience, financial resources, infrastructure and technology deficiency, foreign players' competition and dominance, and geopolitical conditions. Particularly, under the impact and the hidden hand of the neighboring powers and the transnational corporations with overlapped interests, there might be developed conditions on which the governments of Mongolia, Kyrgyzstan and Myanmar will implement an instable policy, and instability, conflicts and rivalries caused by the underground game based on the resource nationalism in the society will emerge in those countries.

\section{Conclusion}

Mongolian, Kazakhstan, Kyrgyzstan and Myanmar are slightly different from each other in a regional location, history, culture, and political and economic systems. However, in recent years, the implementation of political and economic transition to liberalism has been taking place which is in common and these are the countries that might have a similar resources-based economic structure.

The resource curse caused by political and economic instability, governance and institutional stagnation, and high levels of corruption and unequal distribution of wealth which happens commonly in resource-rich developing countries is also taking place in the countries surveyed. However, according to the criteria set by researchers and international research institutions, Kazakhstan and Myanmar are in the politically vulnerable to the resource curse category, and Mongolia and Kyrgyzstan are categorized as affected by the resource curse by their economic systems.

An inherited political system or the Soviet-style regime, the communist system inherited clientelist political relations, a rent seeking government policy, newly developed institutions vulnerability, weak level of the governance quality, and a lack of experience in the resource sector have become prerequisite condition for 
being strongly affected by the "resource curse". In other words, the "resource curse" caused by the political transition challenges and resource-dependence is a process that led to interdependency and degradation.

On the other hand, government policy instability, internal political struggles and risks to national security can happen because of some internal factors such as a country's infrastructure, finance, poor levels of technology, resource nationalism and resource associated poor institutional development, and some external factors such as geopolitical situation, location, neighboring powers' competition for resources and willingness to dominate and so on. Thus, the resource and geopolitical adverse impact occurring in those countries can be considered in the concept "resource geostrategic curse".

On a whole, facing double challenges as a result of their political and economic transition and resource-reliant systems is a similarity that Mongolia, Kazakhstan, Kyrgyzstan and Myanmar are having among the resource-rich developing countries. Therefore, it is possible to consider that so-called "resource curse" which presents several adverse political phenomena such as the stagnation of the institutions, high level of corruption and problems of a rentier state are originated from the consequences of previous political regimes and political system transitions. With those obstacles getting deepened, nowadays resource-reliant situation causes more and more troubles and leads to interdependency. Thus, the risk can affect democratic strengthening that politicians are not potential enough to hold political responsibilities and their function is carrying on in a far distance to public interests, wishes and necessities.

\section{References}

Anderson, J. (1999). Kyrgyzstan: Central Asia's island of democracy? (Postcommunist states and nations). Amsterdam: Harwood Academic Publishers.

AOW. (2012). Burma's resource curse: The case for revenue transparency in the oil and gas sector. Retrieved from http://www.arakanoilwatch.org/. Retrieved from http://www.burmalibrary.org/docs13/Burmas_Resource_Curse(en)-red.pdf

Basedau, M. ( 2005). Context matters-rethinking the resource curse in Sub-Saharan Africa. Working Papers Global and Area Studies, 1, 1-46. Retrieved from http://www.giga-hamburg.de/en/system/files/publications/wp01_basedau.pdf

Basedau, M., \& Mehler, A. (2003). African resources and war. Internationale Politik, Transatlantic Edition, 4(3), 95-100.

Calvo, A. (2014). Kyrgyzstan and natural resources: Challenges ahead. Eurasia Studies Society of Great Britain \& Europe Journal, 3(2), 1-4. Retrieved from http://www.academia.edu/7757492/Kyrgyzstan_and_natural_resources_Challenges_ahead

Carbonnier, G., Wagner, N., \& Brugger F. (2011). Oil, gas and minerals: The impact of resource-dependence and governance on sustainable development. CCDP Working Paper Number 8, 1-36. Retrieved from https://www.lundin-petroleum.com/Documents/cr_CCDP_working_paper.pdf

Collier, P. (2007). The bottom billion. Oxford: Oxford University Press.

Collier, P. (2007). Wars, guns, and votes: Democracy in dangerous places. Harper/Harper Collins Publishers.

EDB. (2014). Country report on Myanmar. Sri Lanka export development board. Retrieved from http://www.srilankabusiness.com/pdf/myanmarmarketprofile.pdf

Gawrich, A., Melnykovska, I., \& Schweickert, R. (2010). More than oil and geography-Neopatrimonialism as an explanation of bad governance and autocratic stability in Central Asia. Paper to be presented at the workshop"Neopatrimonialism in Various World Regions” 23 August 2010. Hamburg: GIGA German Institute of Global and Area Studies. Retrieved from http://www.academia.edu/3125993/More_than_Oil_and_Geography_Neopatrimonialism_as_an_Explanation_of_Bad_Gover nance_and_Autocratic_Stability_in_Central_Asia

Haber S., \& Menaldo V. (2011). Do natural resources fuel authoritarianism? A reappraisal of the resource curse. American Political Science Review, 105(1), 1-26. doi:10.1017/S0003055410000584

Haglund, D. (2011). Blessing or curse? The rise of mineral dependence among low- and middle-income countries. Oxford: Oxford Policy Management. Retrieved from http://www.eisourcebook.org/submissions/1325523556OPMBlessingorcursereport2011.pdf

Humphreys, M., Sachs, D. J., \& Stiglitz, E. J. (2007). Escaping the resource curse. Columbia: Columbia University Press. 
IMF. (2012). Macroeconomic policy frameworks for resource-rich developing countries. Retrieved from http://www.imf.org/external/np/pp/eng/2012/082412.pdf

Mahdavy, H. (1970). Patterns and problems of economic development in rentier states: The case of Iran. London: Oxford University Press.

Marat, E. (2012). Kyrgyzstan: A parliamentary system based on inter-elite consensus. Demokratizatsiya, 325-344. Retrieved from https://www.gwu.edu/ ieresgwu/assets/docs/demokratizatsiya\%20archive/GWASHU_DEMO_20_4/G68164810860GH57/G 68164810860GH57.pdf

Martin, B. (2007). Der Rentierstaats-Ansatz und das problem abweichender Fälle. Zeit-schrift für Internationale Beziehungen, 14(1), 43-70.

Mehlum, H., Moene, K., \& Torvik, R. (2006). Institutions and the resource curse. The Economic Journal, 116(508), 1-20. doi:10.1111/j.1468-0297.2006.01045.x

NRGI. (2013). Resource governance index 2013. Retrieved from http://www.revenuewatch.org/rgi

Reuters. (2015, January 15). Output cut at Kumtor gold mine slows Kyrgyz GDP growth in 2014. Retrieved from http://www.reuters.com/article/2015/01/15/kyrgyzstan-gdp-idUSL6N0UU2K820150115

Schweickert, R. (2015, 6 15). Power distribution and rentierism-Complementary explanations for bad governance in Central Asia? Retrieved from http://www.aecpa.es/uploads/files/modules/congress/10/papers/59.docx

Shahyrov, S. (2014). The geostrategic curse in Post-Soviet States: The cases of Kyrgyzstan and Belarus. Research paper of master degree. Budapest, Hungary.

Stoddard, E. (2012). The resource curse- resource nationalism nexus: Implications for foreign markets. Journal of Energy Security. Retrieved from http://ensec.org/index.php?option=com_content\&view=article\&id=389:the-resource-

curse-resource-nationalism-nexus-implications-for-foreign-markets\&catid=130:issue-content \&Itemid=405

TI. (2014, 7 13). Corruption perceptions index 2014. Retrieved from http://www.transparency.org/cpi

Treffers, R. ( 2010 ). State formation and natural resources in Myanmar and Malaysia. Amsterdam: University of Amsterdam. Retrieved from 2010. http://dare.uva.nl/cgi/arno/show.cgi?fid=186234

WBG. (2014). World governance indicators. Retrieved from http://info.worldbank.org/: http://info.worldbank.org/governance/wgi/index.aspx\#reports 